\title{
The Paradox of New Venture Legitimation within an Entrepreneurial Ecosystem
}

\author{
***Donald F. Kuratko \\ Kelley School of Business \\ Indiana University \\ Bloomington, IN 47405 \\ $\mathrm{Ph}: 812-855-4248$ \\ dkuratko@indiana.edu \\ Greg Fisher \\ Kelley School of Business \\ Indiana University \\ Bloomington, IN 47405 \\ fisherg@indiana.edu \\ James M. Bloodgood \\ College of Business Administration \\ Kansas State University \\ Manhattan, KS 66506 \\ jblood@ksu.edu \\ Jeffrey S. Hornsby \\ Bloch School of Management \\ University of Missouri - Kansas City \\ Kansas City, Missouri 64110 \\ jhornsby@ksu.edu
}

***Corresponding Author

Keywords: Entrepreneurial Ecosystem; New Ventures; Newness; Legitimacy; Innovation.

JEL Codes: L26 (Entrepreneurship); L25 (Firm Performance). 


\section{Abstract}

The current rise in research on entrepreneurial ecosystems notes that many questions are still unanswered. We, therefore, theorize about a unique paradox for entrepreneurs trying to establish legitimacy for their new ventures within and beyond an entrepreneurial ecosystem; that is, when pursuing opportunities with high levels of technological or market newness, entrepreneurs confront a significant challenge in legitimizing their venture within an entrepreneurial ecosystem, while those entrepreneurs pursuing ventures using existing technologies or pursuing existing markets have a much easier path to garnering legitimacy within that ecosystem. However, the diffusion of that legitimacy beyond the ecosystem will be wider and more far reaching for those pursuing the newer elements compared to those using existing technologies or pursuing existing markets, thus creating a paradox of venture legitimation. Prior research outlines approaches for new venture legitimacy but it is unclear when these approaches should be applied within and beyond an entrepreneurial ecosystem. To address this paradox, we integrate ideas from the entrepreneurship and innovation literature with insights from the legitimacy literature to describe how different types of venture newness employ different legitimation strategies which result in different levels of legitimacy diffusion beyond an ecosystem. We conclude with a discussion of our concepts and offer suggestions for future research efforts. 


\section{Introduction}

Entrepreneurship is now regarded as the "pioneership" on the frontier of business (Kuratko, 2017). However, scholars warn that a complete understanding of entrepreneurship can be elusive (Audretsch, Kuratko \& Link, 2015). The impact of entrepreneurial activity is felt in all sectors and at all levels of society, especially as it relates to innovation, competitiveness, productivity, wealth generation, job creation, and formation of new industry (Morris, et al. 2015). Newer entrepreneurial ventures — some of which did not exist 20 years ago — have collectively created millions of new jobs during the past decade. Among many notable examples, consider Facebook, Twitter, Google, LinkedIn, and YouTube.

Amidst the energy and excitement of the entrepreneurial movement has been the rise of "entrepreneurial ecosystems" as coordinated attempts to establish environments that are conducive to the probabilities of success for new ventures following their launch. However, the rise of many ecosystem approaches has left many questions unanswered. As Stam (2015: 1763) so clearly pointed out, "Seductive though the entrepreneurial ecosystem concept is, there is much about it that is problematic, and the rush to employ the entrepreneurial ecosystem approach has run ahead of answering many fundamental conceptual, theoretical and empirical questions."

What exactly is an entrepreneurial ecosystem? Stam (2015: 1764) defines an entrepreneurial ecosystem as "a set of interdependent actors and factors coordinated in such a way that they enable productive entrepreneurship." He goes on to point out that these entrepreneurial ecosystems differ from other concepts (such as clusters, innovation systems, or industrial districts) "by the fact that the entrepreneur, rather than the enterprise, is the focal point. The 
entrepreneurial ecosystem approach thus begins with the entrepreneurial individual instead of the company, but also emphasizes the role of the entrepreneurship context (Stam: 1761).”

If these entrepreneurial ecosystems are focused on creating environments conducive to the success of entrepreneurs and their new ventures, there still exists a challenge for these entrepreneurs to establish their credibility or legitimacy within and beyond that ecosystem for further advancement. The newness of entrepreneurial venture means that such ventures are initially not known and are usually poorly understood within an ecosystem, causing them to lack legitimacy with other individuals and organizations in an ecosystem. New ventures that lack legitimacy struggle to access much needed resources and support (Fisher, Kotha \& Lahiri, 2016), are less likely to forge partnerships or strategic alliances with other organizations (Singh, Tucker \& House, 1986), struggle to garner attention from the media (Pollack \& Rindova, 2003), and risk being overlooked for new contracts (Starr \& MacMillan, 1990). We, therefore, believe that exploring the strategies for an entrepreneur to legitimize his/her new venture is one conceptual element of importance for entrepreneurs within an entrepreneurial ecosystem. Prior research outlines possible approaches for fostering new venture legitimacy (e.g., Navis \& Glynn, 2011; Zimmerman \& Zeitz, 2002) but it is unclear when these approaches should be applied and what the implications of each approach are for the diffusion of new venture legitimacy within and beyond an entrepreneurial ecosystem. As entrepreneurs begin to execute on their new venture concepts, what specific strategies must be considered to effectively convey some legitimacy within the entrepreneurial ecosystem and more significantly in trying to move beyond the ecosystem for success? If entrepreneurs are the focus of these ecosystems, then the quest for attaining legitimacy of their ventures remains a missing link in the current studies. 
To address this gap in the ecosystem literature we proceed with our paper as follows. First, we explore the evasive domain of entrepreneurial ecosystems. Second, we then integrate ideas from three different literatures - entrepreneurship and innovation (to articulate a model for describing relative newness of entrepreneurial ventures), the legitimacy literature (relating different legitimation strategies), and the legitimacy diffusion literature (describing how different types of venture newness and different legitimation strategies result in different levels of legitimacy diffusion). Third, we highlight a key paradox for entrepreneurs within an entrepreneurial ecosystem. That is, when pursuing opportunities with high levels of technological or market newness, entrepreneurs confront a significant challenge in legitimizing their venture within an entrepreneurial ecosystem, while those entrepreneurs pursuing ventures using existing technologies or pursuing existing markets have a much easier path to garnering legitimacy within that ecosystem. However, the diffusion of that legitimacy beyond the ecosystem will be wider and more far reaching for those pursuing the newer elements compared to those using existing technologies or pursuing existing markets, thus creating a paradox of venture legitimation. Finally, we conclude with a discussion of our concepts and offer suggestions for future research efforts.

\section{The Elusive Domain of Entrepreneurial Ecosystems}

While fast becoming popular entities to promote entrepreneurship and foster new venture creation, entrepreneurial ecosystems are not clearly understood as to their exact meaning because they have been defined in a number of ways with differing elements purported to be important. Besides the definition provided by Stam (2015) that was mentioned earlier, Acs, Autio, and Szerb (2014: 479) define an entrepreneurial ecosystem as a, "dynamic, institutionally embedded 
interaction between entrepreneurial attitudes, abilities, and aspirations, by individuals which drives the allocation of resources through the creation and operation of new ventures." In a study of innovation networks, Rampersad, Quester, and Troshani (2010: 794) define those networks as "a loosely tied group of organizations that may comprise of members from government, university, and industry continuously collaborating to achieve common innovation goals." Another popular way to define entrepreneurial ecosystems is based on location within communities or geographic regions (Nambisan \& Baron 2013; Cohen 2006). An ecosystem in this context is defined as an agglomeration of interconnected individuals, entities, and regulatory bodies in a given geographic area (Isenberg 2010; Malecki 2011). Participants in an entrepreneurial ecosystem may include venture start-ups, banks, venture capitalists, incubators, accelerators, universities, professional service providers, and government agencies that support entrepreneurial activity. These varying perspectives motivated Stam (2015) to claim that there is no widely shared definition of entrepreneurial ecosystems. Isenberg (2010) also noted that there is no exact formula for creating an entrepreneurial ecosystem.

Another way to examine this phenomenon is through the elements that are considered most important to an entrepreneurial ecosystem. According to Isenberg (2011) these ecosystems consists of six general domains: a conducive culture, enabling policies and leadership, availability of appropriate finance, quality human capital, venture-friendly markets for products, and a range of institutional and infrastructural supports. Stam (2015) points to nine attributes that include: leadership, intermediaries, network density, government, talent, support services, engagement, companies, and capital. The World Economic Forum (2013) offers eight pillars for a successful entrepreneurial ecosystem: accessible markets; human capital/workforce; funding 
and finance; support systems/mentors; education and training; major universities as catalysts; and cultural support. Isenberg (2010) also developed nine principles important to the building of an ecosystem including: not emulating Silicon Valley; shaping the ecosystem around local conditions; engaging the private sector from the start; stressing the roots of new ventures; emphasizing ambitious entrepreneurship; favoring high potentials; getting a big win; tackling cultural change head-on; and, reforming legal, bureaucratic, and regulatory frameworks. As can be seen, there are many factors offered that describe or prescribe what a successful entrepreneurial ecosystem entails.

The very idea of an ecosystem is predicated on the interdependence of these elements. Ecosystems, however, are inherently complex and little is known about how the different components interact with each other, making it challenging for new ventures seeking legitimacy within that ecosystem. Morris, Neumeyer \& Kuratko (2015) point out that there is a divergence of financial, social, and human capital resources that entrepreneurs have access to in different ecosystems. Comparing entrepreneurial ventures in Silicon Valley to those in Detroit, Michigan, there is quite a difference in which entrepreneurs confront more adverse conditions that limit their overall economic productivity, and how that differs depending on the attributes of the venture they are creating. However, all types of new ventures confront the initial challenge of newness (Kuratko, Morris, \& Schindehutte, 2015), and the associated legitimacy hurdles that make it difficult for such ventures to access resources (Fisher et al., 2016). If, as promoted in Isenberg's (2010) principles, emphasizing ambitious entrepreneurship; favoring high potentials; and getting a big win, are important for those involved in building an entrepreneurial ecosystem, then the challenge of gaining legitimacy for an entrepreneur's venture concept may be a key 
factor for success within and beyond an entrepreneurial ecosystem. Yet, because legitimacy barriers pertain to a venture's newness, gaining legitimacy can be difficult when developing "new" (i.e., novel) concepts. Thus, the element of "newness" with ventures must be considered.

\section{Newness and Legitimacy}

Newness, which is a hallmark of entrepreneurship, is recognized as both an asset and liability for new ventures (e.g. Navis \& Glynn, 2011). Entrepreneurial ventures derive competitive advantage over incumbent organizations by introducing novel technologies into the market and by developing innovative business models that give rise to new market categories (Christensen, 1997; Schumpeter, 1934). But new ventures simultaneously confront a "liability of newness" (Stinchcombe, 1965: 148) because their lack of performance history and consequent relative illegitimacy serves as a burden when they seek to acquire resources and enter into exchange relationships (Aldrich \& Fiol, 1994). New ventures therefore confront a paradoxical challenge in that a primary source of competitive advantage — technological or market newness—can also serve as a significant liability.

To overcome the "liability of newness" associated with a new venture an entrepreneur can work to strategically establish organizational legitimacy by materially and symbolically manipulating elements of the venture (e.g. Delmar \& Shane, 2004; Martens et al., 2007; Navis \& Glynn, 2011; Sine, David \& Mitsuhashi, 2007; Zimmerman \& Zeitz, 2002; Zott \& Huy, 2007). Legitimacy is derived from the perception that a new venture is "desirable, proper, or appropriate within some socially constructed system of norms, values, beliefs, and definitions" (Suchman, 1995: 574). Prior literature has described the actions that entrepreneurs can take to strategically establish the 
legitimacy of a new venture. Strategies employed to establish organizational legitimacy include conforming to existing rules and norms, selection of favorable contexts, manipulation of cultural environments and the creation of new social contexts (Zimmerman \& Zeitz, 2002). There is however little guidance on when each of these strategies should be employed and how the different legitimation strategies impact the spread or diffusion of new venture legitimacy within and beyond an existing ecosystem.

Hence we seek to conceptually address the following research questions in this paper: First, when are different legitimation strategies employed to legitimize a new venture within an ecosystem? Second, how do the legitimation strategies employed relate to the diffusion of new venture legitimacy beyond an existing entrepreneurial ecosystem?

To address these questions, we integrate ideas from three different literatures. First, because legitimation is related to newness, we utilize the entrepreneurship and innovation literatures (e.g. Benner \& Tushman, 2003) to articulate a model for describing relative newness of entrepreneurial ventures. Second, we build on ideas from the legitimacy literature (e.g. Zimmerman \& Zeitz, 2002) to relate venture newness to different legitimation strategies thereby explaining when and why different new venture legitimation strategies are employed. Third, we integrate ideas from the legitimacy diffusion literature (e.g. Johnson et al., 2006; Tost, 2011) to describe how different types of venture newness and different legitimation strategies, result in different rates and levels of legitimacy diffusion within and beyond an entrepreneurial ecosystem. The conceptual insights that emerge from the integration of these literatures highlight a key challenge for new ventures within an entrepreneurial ecosystem: entrepreneurs 
that pursue opportunities leveraging high levels of technological and market newness confront the greatest challenge in legitimizing their venture; but if they can clear a legitimacy threshold, their ventures will experience higher levels of legitimacy diffusion beyond their existing entrepreneurial ecosystem compared to ventures with lower levels of technological and market newness. Conversely entrepreneurs that create new organizations embracing existing technology for an existing market category have an easier time legitimizing their venture within their ecosystem but the diffusion of new venture legitimacy beyond their existing ecosystem is more limited.

\section{Innovation Newness: Dimensions and Level}

Innovation is a driving force in the entrepreneurial process (Drucker, 1985). While numerous definitions of innovation have surfaced in the research over the years (see Crossan \& Apaydin, 2010), we focus on innovation as the generation and implementation of new ideas, processes, products or services (Garcia \& Calantone, 2002).

Schumpeter (1934) stressed the novelty or "newness" aspects of innovation such as new markets, new goods, new methods, new structures, etc. New market opportunities (Mueller et al., 2012) and new technological developments (Eckhardt \& Shane, 2011) produce significant entrepreneurial opportunities. Mueller et al. (2012) describe market pioneering as a particular form of entrepreneurial behavior whereby an organization proactively creates a new productmarket arena that others have not recognized or actively sought to exploit. Organizations that consistently exhibit such market pioneering behaviors are able to capitalize on potential firstmover advantages (Garrett, Covin, \& Slevin, 2009; Covin, Slevin, \& Heeley, 2000). Eckhardt 
and Shane (2011) evaluated 201 industries over a 15-year period to validate that technological innovation is a key determinant of entrepreneurial opportunity. Past research therefore suggests that the newness of innovations can broadly be distinguished on two key dimensions: (1) technology newness and (2) market newness (Abernathy \& Clark, 1985; Benner \& Tushman, 2003; Zhou et al., 2005). Technology newness represents technological advances while market newness represents efforts to establish a new product-market arena to nurture new customers for a product or service (Benner \& Tushman, 2003; Zhou et al., 2005)

Innovations that are exploited within an entrepreneurial venture also vary in the level of newness that they encapsulate; the terms incremental and radical innovation have been used to describe differing levels of newness (Tushman \& Anderson, 1986; Henderson \& Clark, 1990). Incremental innovations are minor changes in existing technology, simple product improvements, or line extensions that fit within or minimally alter an existing market category. In contrast, radical innovations are novel advances that substantially shift a technological trajectory and/or establish the basis for a new market category (Zhou et al., 2005; Wind \& Mahajan, 1997).

\subsection{Newness Framework}

Entrepreneurs have the option to exploit opportunities by leveraging incremental or radical technological advances to provide a good or service with incremental or radical market disruption (Lumpkin \& Dess, 1996; Navis \& Glynn, 2011). Linking the different dimensions of innovation newness - technology newness and/or market newness - with the level of innovation 
newness - incremental versus radical innovations — provides a framework for broadly classifying the overall "newness" of an innovation within an entrepreneurial venture (See Figure 1).

Insert Figure 1 about Here

At one extreme, entrepreneurs can exploit a radical new technology to provide a product or service intended to radically disrupt the market through the creation of a new product-market space. Such an entrepreneur embraces the highest level of innovation "newness" relative to other alternatives. The members of the venture need to participate in the establishment of the new market category they are creating and in so doing they need to develop a base of knowledge and foster public acceptance and recognition of the emergent category (Aldrich \& Fiol, 1994; Navis \& Glynn, 2010, 2011). Furthermore, because they are exploiting a radical technology, they confront high levels of technological uncertainty and they need to help the market understand, accept and embrace a new technological advance (see Quadrant D in Table 1). At the other extreme, entrepreneurs that create an organization to exploit or incrementally improve on an existing technology and seek to operate within an established market category confront the lowest levels of innovation "newness" relative to other alternatives (see Quadrant A in Table 1).

Between these two extremes, some entrepreneurs may create and exploit a radical new technology to establish a venture to compete in an existing market category (Quadrant C in Table 1). Also between the two extremes, a new venture may exploit and incrementally improve on an existing technology but participate in the establishment of a new market category (Quadrant B in Table 1). 
In the past, the dimensions of newness (technological and market) and the levels of newness (radical and incremental) have provided a basis for understanding how a firm's market orientation is related to successful breakthrough innovation (Zhou et al., 2005). The dimensions and levels of newness have also been outlined as elements to consider in making decisions with respect to a firm's innovation portfolio (Day, 2007) and for understanding the link between project evaluation criteria and project success (Carbonell-Foulquie, Munuera-Aleman, \& Rodriguez-Escudero, 2004). Therefore, the concepts of newness dimensions and levels have been useful in understanding links between innovation and firm performance, but to date these dimensions have not been jointly utilized to evaluate legitimacy pressures on new ventures, and to consider potential responses to those pressures.

In addressing our research questions, the different levels and dimensions of "innovation newness" provide a basis to consider how different legitimation strategies may help overcome the "liability of newness" associated with new venture creation. This may be particularly important within an entrepreneurial ecosystem seeking to focus on the entrepreneur and yet trying to elevate the "winners" for eventual success. Next we reflect on the theory pertaining to legitimacy judgments to connect innovation newness with new venture legitimation within and beyond an entrepreneurial ecosystem.

\section{New Venture Legitimation Strategies}

Prior research indicates that successful legitimation of new ventures partially explains many positive entrepreneurial outcomes including organizational emergence (Tornikoski \& Newbert, 
2007), venture survival (Delmar \& Shane, 2004; Sine et al. 2007), access to venture capital (Zott \& Huy, 2007) and firm valuation (Martens et al., 2007).

A lack of legitimacy is a crippling problem, particularly for new ventures within an entrepreneurial ecosystem that develop a radical new technology or seek to disrupt a market by creating a new category (Aldrich \& Fiol, 1994; Navis \& Glynn, 2011). Since the activities of such a venture are not widely known or well-understood, the ecosystem partners and supporters are less likely to accept and support what they are doing, meaning that the entrepreneurial ecosystem cannot fulfill its purpose of enabling and fostering productive entrepreneurship. Because of the challenge that entrepreneurs confront in fostering legitimacy for a new venture, some scholars have proposed strategies that can be employed to foster new venture legitimacy. These strategies are particularly relevant within the context of an entrepreneurial ecosystem because they focus on a venture's relatedness to its external environment. Zimmerman and Zeitz (2002) suggest there are four basic legitimation strategies available to new venturesconformance, selection, manipulation and creation. We highlight each as follows:

Conformance strategy. A new venture that conforms does not question, change, or violate the social structure but rather "follows the rules." A conformist strategy signals allegiance to the cultural order and pose few challenges to established institutional logics (Meyer \& Rowan, 1991; Suchman, 1995). Thus, it is a strategy of fitting into the local ecosystem context of firms so as to be seen as legitimate. Zimmerman and Zeitz (2002) point out that conformance is a widely used legitimation strategy for new ventures.

Selection strategy. A selection strategy involves locating in a favorable environment such as an entrepreneurial ecosystem (Scott, 1995; Suchman, 1995). For the new venture, selection allows for the choice of an environment that is consistent with and advantageous for the new venture. If an entrepreneur has the insight and resources to select a favorable environment, then the selection strategy can be highly effective for attaining legitimacy (Zimmerman \& Zeitz, 2002). 
Manipulation strategy. Manipulation is the attempt to make changes in the current ecosystem environment to achieve consistency between an organization and its environment (Zimmerman and Zeitz, 2002). This may involve getting rules and regulations changed so that a new venture can legitimately engage in an activity that was previously disallowed. Because manipulation involves changing some of the scripts, rules, norms, values, logics or models that exist in a particular ecosystem it requires more effort and is more strategic than selection and compliance legitimation strategies (Zimmerman and Zeitz, 2002).

Creation strategy. A creation legitimation strategy requires that an entrepreneur create a new social context by creating new rules, norms, values, scripts beliefs, models, etc. New ventures, especially those in new industries or attempting to establish new market categories, "often uncover new domains of operations that lack existing scripts, rules, norms, values, and models" (Zimmerman and Zeitz, 2002: 422). Therefore, the basis from which new ventures derive legitimacy may not necessarily be established, requiring a creative entrepreneur to act as a pioneer in order to establish the basis of legitimacy for those that come after it (Anderson \& Zeithaml, 1984; Miller \& Dess, 1996). Creation is the most strategic of the four new venture legitimation strategies in that it offers an entrepreneur the most latitude in deciding what he/she will do to legitimate a new venture, yet it is also the most challenging to achieve a positive outcome (Zimmerman \& Zeitz, 2002).

The four legitimation strategies are conceptualized to sit on a punctuated continuum from less strategic to more strategic. Conformance is the least strategic, requiring the lowest level of intervention and no enactment of change in the external environment, and the creation strategy is the most strategic as it requires a high level of intervention and the establishment of a new external environment. Selection falls toward the conformance end of the continuum and manipulation towards the creation end. The more strategic a legitimation strategy, the costlier it is for an entrepreneur to implement it (Zimmerman \& Zeitz, 2002). Conformance as the least strategic legitimation strategy is also the least costly to implement because it requires the lowest level of change within an existing ecosystem. Creation, as the most strategic legitimation strategy, is the costliest to implement because it requires the highest level of change within an existing ecosystem, potentially even the establishment of a new ecosystem. Selection is less 
costly than manipulation and creation, but costlier than conformance, while manipulation is less costly than creation, but costlier than conformance or selection.

Although the existing research provides useful descriptions of and insight into the different legitimation strategies available to entrepreneurs, there is no theory predicting when each of the respective strategies should be used, especially when developing a venture within an entrepreneurial ecosystem. Zimmerman and Zeitz (2002: 428) suggest that researchers should "look at the conditions under which each strategy is most effective". To address this issue, we consider how the dimensions and levels of innovation "newness" in entrepreneurial ventures relate to the legitimation strategies employed, to foster legitimacy within an entrepreneurial ecosystem. We focus on identifying the most effective cost-benefit tradeoff of different legitimation strategies in different scenarios. We strive to isolate the legitimation strategy that is most likely to allow for a new venture to be perceived as legitimate within an entrepreneurial ecosystem at the most effective cost to an entrepreneur.

\section{Innovation Newness and Legitimation Strategies}

The framework we described earlier (Figure 1) provides a basis for classifying the market and technological newness within an entrepreneurial venture. In this section we consider how the innovation newness within a venture is related to the legitimation strategy employed. We work through the four quadrants in Figure 1 to link innovation "newness" to the appropriate legitimation strategy. 
Incremental technology and incremental market innovation. Entrepreneurs that incrementally advance existing technology and operate a venture in an existing market category [Quadrant A in Figure 1] can link the explanation of what they are doing to existing institutional structures within an ecosystem in an effort to attain legitimacy (Aldrich \& Fiol, 1994; Navis \& Glynn, 2011). To garner legitimacy for the venture, the technology can be described with reference to existing products or services that utilize similar technology and the product or service can be compared to other products or services in the same market category or ecosystem. As Suchman (1995: 587) points out, "this type of adaptation does not require [entrepreneurs] to break out of prevailing cognitive frames (Oliver, 1990); rather, the conformist can turn a liability into an asset, taking advantage of being a cultural "insider"'. Because the existing rules, norms, values, beliefs and models are well established (for that particular entrepreneurial ecosystem) an entrepreneur merely needs to comply with the rules and expectations of the partners in that ecosystem to garner legitimacy for the venture. Using an example from the transportation community, Luxgen - the Taiwanese car manufacturer launched in 2009-leveraged existing automobile technology to compete in the established SUV and sedan automobile categories in China. Luxgen was able to conform to the established practices and norms of the transportation community to be perceived as legitimate; Luxgen cars were made to look very similar to the models of existing car brands within the automobile ecosystem, they were distributed through a network replicating existing industry practices, and their showrooms looked very similar to competitors (http://www.gtplanet.net/forum/). By conforming to industry and ecosystem norms and "fitting in" with the expectations of the transportation community, Luxgen was quickly able to quickly and cost effectively acquire legitimacy. The preceding arguments suggest the following: 
Proposition 1: When launching a new venture with incremental technological advancements to enter an existing market category, a conformance legitimation strategy will likely provide the most valuable cost-benefit tradeoff for attaining legitimacy within an entrepreneurial ecosystem, compared to other alternatives.

Conformance is the most frictionless means for an entrepreneur to acquire legitimacy for a new venture because it does not require the entrepreneur to change anything in the institutional environment (e.g., the entrepreneurial ecosystem). The focus of a conformance strategy is on fitting in with the norms and standards of an existing entrepreneurial ecosystem; hence the entrepreneur has to do very little institutional work to attain legitimacy (Lawrence \& Suddaby, 2006; Suchman, 1995). Because conformance requires limited institutional work with an ecosystem, adopting such a strategy minimizes the costs and risks of attaining new venture legitimacy. As such, entrepreneurs will tend to default to a conformance strategy where it is possible to do, but in some cases it is not possible to merely conform because aspects of the venture don't naturally fit within the established ecosystem. In such cases an entrepreneur must adopt either a selection, manipulation or creation legitimation strategy.

Radical technology and incremental market innovation. New ventures that develop a new technology to enter an existing market category [Quadrant B in Figure 1] face an increased legitimacy hurdle because the audience within an entrepreneurial ecosystem is likely unfamiliar with, and therefore uncertain about the new technology being introduced by the venture. The development of a new technology therefore exacerbates the liability of newness of an entrepreneurial venture. While the development of a new technology increases the legitimacy liability for the venture within an ecosystem, by operating in an existing market category, an entrepreneur can link aspects of the venture to existing institutional infrastructure to attain legitimacy (Aldrich \& Fiol, 1994; Navis \& Glynn, 2011). The venture can readily be compared 
to other products or services in the category. Because social objects are evaluated via categories, fitting in with an existing category confers meaning and order, thereby enhancing the legitimacy of an object being evaluated. Zuckerman (1999) referred to this as the "categorical imperative." Under such conditions an entrepreneur can enhance new venture legitimacy by carefully selecting a market category, ecosystem and/or an early customer base for the new product or service (Zimmerman \& Zeitz, 2002). By selecting a market category, ecosystem and/or a customer base made up of "early adopters" for whom trying out a new innovation is normal and appealing (Rogers, 2010), an entrepreneur can allow a venture with a new technology to quickly gain acceptance. For example, returning to the transportation community, Tesla Motors - the new electric car manufacturer that emerged in the early 2003-first produced an electric "sports car". Tesla focused on developing "innovative battery and charging technology" to gain "a substantial lead in making batteries cheaper and recharging quicker than its competitors" (http://www.technologyreview.com). But Tesla also created vehicles that looked somewhat similar to and compete with other high-end, luxury "sports cars" thereby fitting into an existing market category. The legitimacy of Tesla was strategically managed by locating the company on the West Coast of the USA (e.g., Silicon Valley) where innovation and novelty are embedded in that regional ecosystem (Saxenian, 1996). If Tesla motors had been located in an area with fewer early adopters where innovation is less readily embraced, then it would likely not have gained legitimacy so quickly or it would have been much costlier for it to do so. This example and the preceding arguments suggest the following proposition:

Proposition 2: When launching a new venture with radical new technology to enter an existing market category, a selection legitimation strategy will likely provide the most valuable cost-benefit tradeoff for attaining legitimacy within an entrepreneurial ecosystem, compared to other alternatives. 
The legitimation strategy of selection takes more effort and comes with more risk than mere conformance because the entrepreneur needs to find an appropriate ecosystem and figure out how to operate in that ecosystem; therefore, selection will only be used when the entrepreneur does not have the option to merely conform as a means to gain venture legitimacy. Yet the selection strategy is less costly and less risky than manipulation or creation. Therefore, entrepreneurs will use a selection strategy more readily than manipulation or creation where possible. However, there are situations when the newness of the venture necessitates that an entrepreneur utilizes manipulation or creation strategies to overcome the legitimacy hurdles confronting the venture.

Incremental technology and radical market innovation. New ventures that exploit existing technology to radically disrupt a market by creating a new market category [Quadrant $\mathrm{C}$ in Figure 1] operate in an institutional void because the norms and expectations of their context are not yet established. The venture's product or service does not fit into an existing category, therefore it is difficult for audiences to evaluate it, and as such, the legitimacy of the new venture is questioned (Zuckerman, 1999). Although the venture leverages an existing technology, which increases understanding and acceptance of the organization, that technology is being used in a new way to create a new market category, therefore the entrepreneur needs to change the perception of the audience within an ecosystem about how the technology should be applied. Therefore, the entrepreneur needs to manipulate people's perceptions of the technology so that they can view it in a new way. For example, once again in the transportation community, Zipcar — the car sharing venture launched in 2001—utilized existing automotive and wireless technology to create a service that would be at the forefront of the new car sharing market 
category in the USA (Hart, Roberts \& Stevens, 2005). The Zipcar founders needed to manipulate the transportation community's perceptions about car ownership and motor vehicle use to get them to embrace the concept of car sharing. To do so, Zipcar agents worked to help them understand that the norms associated with traditional car rentals could be changed to make it appealing to a very different audience (Hart et al., 2005). Thus they were required to manipulate perceptions and norms of those within their ecosystem to gain legitimacy for the venture. As part of educating the public and other stakeholders, the media can play a significant role especially when a market is emerging (Rindova, Petkova \& Kotha, 2007). In these situations, entrepreneurs need to be especially cognizant of managing their message. Hence, we propose:

Proposition 3: When launching a new venture that uses existing technology to create a new market category, a manipulation legitimation strategy will likely provide the most valuable cost-benefit tradeoff for attaining legitimacy within an entrepreneurial ecosystem, compared to other alternatives.

Manipulation as a legitimation strategy requires entrepreneurs to make changes to their environment to achieve consistency between the organization and its environment, yet changing the environment is difficult. When dealing within an entrepreneurial ecosystem, it is very difficult for the entrepreneur to spend the time and money convincing the different constituents to understand the new market category. Zimmerman and Zeitz (2002: 425) explain that a "single new venture, by itself, generally lacks the money or power to significantly manipulate its environment (Brint \& Karabel, 1991; DiMaggio \& Powell, 1983; Fligstein, 1991; Meyer \& Rowan, 1977; Powell, 1991).” Because of the challenges associated with a manipulation legitimation strategy within an entrepreneurial ecosystem, entrepreneurs will only employ the effort and incur the cost to adopt such a strategy if a conformance or selection manipulation strategy won't suffice. Yet in some extreme cases, where entrepreneurs are launching a venture 
that seeks to develop a new technology that will create a new market category, a manipulation strategy may not suffice and a creation strategy may be required to achieve venture legitimacy.

Radical technology and radical market innovation. New ventures that develop a radical new technology and utilize it to create a new market category [Quadrant D in Figure 1] face the greatest legitimacy challenge. The norms and expectations of their market context are not established and the technology underlying the venture is unfamiliar. Hence an entrepreneur creating a venture of this nature faces the challenge of having to create new rules, norms, values, beliefs or models. Not only do they need to explain a new technology to the ecosystem audience, they also need to create the language and terminology to provide such explanations. In certain instances, the entrepreneur may actually be required to create a new ecosystem around their venture, to support what they are doing. The construction of a new market for a venture with a new technology thus depends on the entrepreneur drawing on characteristics of other fields that contain descriptions evoking the "new" message of the entrepreneur (Stringfellow, Shaw \& Maclean, 2014). As Zimmerman and Zeitz (2002) point out: "Creation is especially evident in the introductory stage of new industries. It is the most strategic of the four strategies." For example, SpaceX is a new venture that extends the transportation industry into space exploration, thereby creating a new category of travel. To do this SpaceX "designs, manufactures and launches advanced rockets and spacecraft... [The venture] was founded to revolutionize space technology, with the ultimate goal of enabling people to live on other planets" (http://www.spacex.com/about). In so doing SpaceX has to create the rules, norms, and models for civilian space travel if they are to be perceived as a legitimate organization to the entrepreneurial ecosystem. Furthermore, because SpaceX leverages cutting edge technology, the 
entrepreneurs behind the venture have to develop the advanced technology and provide (or even create) ecosystem partners with an understanding of how it works. This example illustrates how entrepreneurs exploiting a new technology to enter or create a new market category need to create the social context for such ventures and therefore the creation legitimation strategy must dominate. Thus we propose:

Proposition 4: When launching a new venture with a radical new technology that is used to create a new market category, a creation legitimation strategy will likely provide the most valuable cost-benefit tradeoff for attaining legitimacy within an entrepreneurial ecosystem, compared to other alternatives.

Because of the costs, risks and challenges associated with creation as a legitimation strategy, entrepreneurs only employ it when the other legitimation strategies of conformance, selection and manipulation are not viable or are unlikely to have the desired effect. As the most strategic and costly of the legitimation strategies (Zimmerman and Zeitz, 2002) it creates the most work for entrepreneurs hence they should only adopt it when they have no other choice.

Having described the link between the dimensions and levels of innovation "newness" and the legitimation strategies utilized in such ventures we now consider how utilizing each of these legitimacy strategies may impact the spread of legitimacy for a new venture beyond an entrepreneurial ecosystem. The spread of legitimacy is a key issue for entrepreneurs with new ventures because it provides a basis for them to become known and accepted within an ecosystem and more broadly and thereby provides a basis for the firm to acquire resources and access customers within and beyond an existing entrepreneurial ecosystem. Legitimacy diffusion is thus an antecedent to venture growth, and because venture growth is a key concern in entrepreneurship research and practice (Gilbert, McDougall \& Audretsch, 2006; McKelvie \& 
Wiklund, 2010), the diffusion of new venture legitimacy beyond an entrepreneurial ecosystem is a highly pertinent issue.

\section{Legitimacy Assessment and Audience Diversity}

Since legitimacy assessments represent social judgments that reside in the eye of the beholder (Ashforth \& Gibbs, 1990; Bitektine, 2011), such assessments are audience dependent (Suchman, 1995). It is conceivable that technology and market "newness" may be perceived differently by different actors in the ecosystem and beyond. For example, what may seem to be incremental newness to one actor familiar with a certain technology may be deemed more radical by those outside of the technological sphere. The same may hold true for a market. One actor who may be quite familiar with a market could perceive the market newness as incremental yet someone with less understanding of that market may deem it a far more radical approach. We therefore recognize that entrepreneurs must manage new venture legitimacy judgments across diverse audiences with different interpretations of technology and market newness in an entrepreneurial ecosystem, so as to appear legitimate to garner needed resources for venture survival and growth.

Recently scholars have highlighted that different new venture supporters likely operate with contrasting institutional logics, and thus an institutional logics perspective provides a theoretically meaningful basis to distinguish between different categories of new venture audiences (Pahnke, Katila \& Eisenhardt, 2015). Using institutional logics that characterize different new venture audience groups as a basis for uncovering how and why the legitimacy criteria for a new technology venture may vary depending on the audience, Fisher, Kuratko, Bloodgood, and Hornsby (2017) identified the varying logics of different actors important to new 
ventures. For example, crowdfunding backers tend to operate primarily with a community logic, government agents with a state logic, angel investors with a market logic, venture capitalists with a professional logic, and corporate venture capitalists with a corporate logic.

Fisher, et al. (2017) utilized research on framing to describe how technology entrepreneurs may use emphasis framing to deal with the challenge of establishing new venture legitimacy with different audiences operating with different institutional logics and thereby improve their chances of accessing critical resources for venture survival and growth. They demonstrated that emphasis frames enable entrepreneurs to quickly and strategically adjust salient elements of their presentations, pitches, videos, documents, or meeting discussions to emphasize specific legitimacy mechanisms that align with the institutional logic of the focal audience.

Therefore, while the acknowledgment of different perceptions by different actors in an entrepreneurial ecosystem is important, the research suggests that by strategically framing the presentation of their venture to differing actors, entrepreneurs can be effective garnering legitimacy within and beyond an entrepreneurial ecosystem.

\section{New Venture Legitimacy Diffusion}

Past research has examined the general legitimacy diffusion process of a social object (Johnson et al., 2006; Tost, 2011). This research describes legitimacy diffusion as a phased process beginning with innovation, followed by local validation, diffusion and general validation (Johnson et al., 2006). Along these lines, we outline how new ventures move through a similar phased process of legitimation and legitimacy diffusion. The first phase is the innovation phase 
in which different dimensions and levels of newness - technology and/or market newness — are injected into a new venture. The second phase is the strategy phase in which an entrepreneur adopts a strategy to garner legitimacy for a venture. This may be a conformance, selection, manipulation or creation strategy. The third phase is the local-validation phase in which individuals in an existing entrepreneurial ecosystem judge the legitimacy of a new venture. Individuals making legitimacy judgments may do so passively or they may engage in more of an active evaluation process (Tost, 2011). The final phase is the diffusion phase in which the knowledge and understanding of a venture spreads beyond a local entrepreneurial ecosystem to a broader population and is more generally validated. Broad diffusion, beyond an existing ecosystem, is measured in terms of reach, narrow to wide. Reach reflects how far knowledge and acceptance of a venture disperses. The columns of Table 1 reflect the different phases of the legitimacy diffusion process for new ventures and the contents of each column highlight the various inputs and output of legitimacy diffusion.

Insert Table 1 about Here

Column one reflects the different categorizations of innovation newness in new ventures ranging from lower levels of newness to very high levels of "newness". Column two reflects the legitimation strategies associated with the different levels of newness as described in Propositions 1-4. Column three reflects the nature of local legitimacy judgments within an entrepreneurial ecosystem. Column four reflects the reach of legitimacy diffusion beyond an entrepreneurial ecosystem. The columns of Table 1 are integrated into process diagram in Figure 2. Figure 2 highlights the key phases and relationships between constructs in the various phases of new venture legitimation within and beyond an entrepreneurial ecosystem. The local 
validation phase and legitimacy diffusion phase are the focus of the next portion of our theorizing.

Insert Figure 2 about Here

\subsection{Local Validation}

Recent research recognizes that a social object's legitimacy is not only dependent on the strategies employed to foster legitimacy, but also on how individual evaluators assess the output from such strategies (Tost, 2011). As Suchman points out: “[Organizational legitimacy] represents a relationship with an audience, rather than being a possession of the organization" (Suchman, 1995: 594). Hence, the quest for new venture legitimacy typically involves managing and satisfying the expectations of individual members of an organization's immediate audience. ${ }^{1}$ Therefore, if the legitimacy of a venture is to diffuse, a local audience first needs to validate the venture (Johnson et al., 2006; Tost, 2011). For a new venture, the local audience consists of the individuals within an entrepreneurial ecosystem that come into direct contact with the venture and its founders as it becomes established. As the individual members of an entrepreneurial ecosystem are exposed to a new venture, so they assess its component parts to consider whether it fits with their expectations to validate it as legitimate. The level of cognitive effort employed to make such assessments can range from passive (i.e. unconscious, intuitive) to active (i.e. effortful, engaging) (Kahneman, 2011; Tost, 2011).

\footnotetext{
${ }^{1}$ In most entrepreneurial ecosystems individuals make legitimacy assessments; we therefore theorize under the assumption legitimacy assessments are carried out by individuals. However, in some instances, judgments of new venture legitimacy may be made at a firm level e.g. when a firm is considering whether or not to enter into an exchange relationship with a new venture. The process of new venture legitimacy assessment has the potential to be more complex when being made at a firm level, because it may account for conflicting interpretations and assessments of different individuals within a firm. To keep our theorizing focused and parsimonious, we don't attempt to account for what might happen when firms are forced to make new venture legitimacy assessments.
} 
Passive assessments. At the passive extreme of legitimacy assessments, individuals within an ecosystem may automatically validate a venture as legitimate because it immediately aligns with their cultural expectations (Tost, 2011). They engage in very little effort to understand exactly what the venture does, or how the different elements of the venture relate to one another. Rather they just assume the venture is legitimate because nothing about the venture conflicts with their expectations. Legitimacy judgments are made in this way because, as prior research highlights, individuals prefer not to engage in effortful cognitive work if they can avoid it (Fiske \& Taylor, 1984; Kahneman, 2011). Therefore, if there is no identifiable reason to expect that a venture may be illegitimate within an entrepreneurial ecosystem, then the automatic individual response may be to validate it as legitimate. As Johnson et al. explain, sometimes legitimacy may be acquired “simply by not being implicitly or explicitly challenged" (2006: 60).

Active assessments. The active end of the assessment continuum reflects effortful attempts on the part of individuals within an entrepreneurial ecosystem to validate the legitimacy of a new venture (Tost, 2011; Kahneman, 2011). At this extreme an individual is motivated or compelled to consciously invest time and energy into constructing a legitimacy judgment. Research indicates that individuals typically need to have a reason to engage in such cognitive effort; some feature of the situation needs to demand that they carefully consider the judgment that they are making, otherwise they will revert to a passive mode of assessment (Kahneman, 2011).

The legitimation strategies adopted by an entrepreneur to legitimate a new venture may serve as a prompt for active legitimacy assessment by individuals within an entrepreneurial ecosystem. If a conformance strategy is adopted to legitimate a new venture, then the venture is positioned to 
just "fit in" with its institutional context, and there is nothing to prompt a local audience to question its reason for being within the ecosystem. However, as the legitimation strategy of an entrepreneur becomes more strategic local evaluators within an entrepreneurial ecosystem need to think more carefully about whether the features of the venture are appropriate (Tost, 2011). As described earlier, the legitimation strategies fall on a punctuated continuum from least strategic (conformance) to most strategic (creation). The more an entrepreneur tends toward the highly strategic end of the continuum, the more the individuals making legitimacy judgments within an ecosystem will be forced to confront something new or unexpected when evaluating the venture, therefore the higher the likelihood that they will shift from a passive to active assessment mode (Tost, 2011).

A conformance legitimation strategy results in a passive validation because conformance means that nothing new or unexpected is introduced for the local ecosystem audience to consider. When a conformance legitimation strategy is employed the venture immediately appears legitimate because everything is aligned with the venture's environment (Zimmerman \& Zeitz, 2002). Thus, when a conformance strategy is employed the local validation of new venture legitimacy within an entrepreneurial ecosystem is most likely a passive assessment. Conversely, at the other end of the legitimation strategy continuum, a creation legitimation strategy involves significant change and divergence for an evaluator to process. A creation strategy means that an entrepreneur attempts to develop "something that did not already exist in the environment" (Zimmerman \& Zeitz, 2002, p. 425), new "rules, norms, values, beliefs (and) models" (p. 423). Because of the high level of newness and lack of familiarity associated with the creation strategy, those within an ecosystem judging the legitimacy of a new venture need to carefully and 
deliberately assess the venture and its relatedness to the environment to judge whether it is legitimate. Therefore, when a creation strategy is used to foster new venture legitimacy then the local ecosystem audience most likely engages in an active assessment process to validate the legitimacy of a venture, so as to process and comprehend the new, unfamiliar information associated with the creation strategy.

Proposition 5: As the legitimation strategies adopted in a new venture become more strategic the local validation of new venture legitimacy within an entrepreneurial ecosystem will most likely shift from passive to active assessment.

\section{Legitimacy Brokering and Diffusion}

When an evaluator makes a legitimacy judgment about a new venture, they may inform others within their social network of their views (Davies \& Prince, 2005). The sharing of information between actors in a social network is referred to as information brokering. There is a cost to information brokering to both the initiator and the receiver (Burt, 2005). The costs include potentially losing trust if brokered information turns out to be useless or damaging plus the opportunity costs of not engaging in other activities (including giving or receiving information in other brokering situations). A benefit for an initiator might come from reputational and status enhancements within the network if the brokered information is meaningful (Berger, 2013), or from getting others to do something the initiator wants done. For recipients of information brokering, the benefits might involve receiving unique or affirming information (Burt, 2005). For social actors to actively engage in information brokering activities, they need to perceive that the benefits from brokering outweigh the costs.

Brokering activities are critical for the spread of information about new ventures beyond their local entrepreneurial ecosystem. Direct interaction between members of a network provides an 
opportunity for sharing legitimacy views (Burt, 1987). Often, public sources of information about new ventures are relatively scarce, so any information coming from more private sources, such as network connections, are valued (Sorenson \& Stuart, 2001). Ongoing, communications with network members also provide learning opportunities for network members whereby they can reconsider their views and potentially assimilate toward other members' viewpoints (Alexy \& George, 2013). Moreover, network members are a more trusted source of new information compared to sources outside one's network (Stuart \& Sorenson, 2007). Networks, especially dense ones that may have strong ties, provide sanctions as well as rewards, and thus provide an incentive to members to share valuable information so that members will not be perceived as withholding valuable information or promoting disingenuous information. However, not all information is considered worthy of sharing with others. If there is nothing surprising or interesting about new information, then it is less likely to be shared within a social network (Berger, 2013). Research in the marketing literature suggests that novel and distinguishable information is more likely to be shared within a network, even though it can be more difficult to explain (Elfring \& Hulsink, 2003), because such information provides "social currency" for the broker-people like to share things that make them look good (Berger, 2013). Novel and distinguishable information is more likely to make a broker look good because it signifies the introduction of new value and insight into a network.

Relating this back to new venture legitimacy judgments, where individuals have made passive judgments about the legitimacy of a venture, they are less likely to be conscious of novel and distinguishing features of the venture. Passive judgments are associated with conformance legitimation strategies (see proposition 5) and in the process of making passive legitimacy 
judgments the features and dimensions of the venture are not consciously accounted for (Tost, 2011); therefore, information about the venture is unlikely to be brokered with others outside of an entrepreneurial ecosystem. Conversely, where an individual evaluator within an ecosystem has engaged in a conscious and active assessment of a new venture's legitimacy, they are more likely aware of its unique and distinguishing features. Moreover, active evaluation is associated with entrepreneurial ventures that engage in a creation strategy to foster legitimacy (Proposition 5) and such ventures are likely to encapsulate the highest level of innovation "newness" (Proposition 4). Therefore, where an individual has to engage in a very active evaluation process to assess a new venture's legitimacy it means that the new venture likely has technology and or market features that are novel and distinguishable which are more likely to be shared with others outside on an entrepreneurial ecosystem, because information about the venture serves as "social currency" for the broker (Berger, 2013).

Thus when new technologies and/or markets are the primary focus of a venture there is much for individuals within an entrepreneurial ecosystem to accentuate when interacting with others outside of the existing ecosystem. And this new information and knowledge can be highly sought after by those outside of an entrepreneurial ecosystem (Bae, Wezel and Koo, 2011). This will enhance the level of information brokering about the venture. Conversely, when a new venture focuses on existing technologies and markets there is little for actors to share with others about the venture and this can limit brokering.

Proposition 6: Active evaluation of new venture legitimacy is positively related to new venture legitimacy brokering activities with others outside of an existing entrepreneurial ecosystem resulting in legitimacy diffusion.

The diffusion of legitimacy for new ventures beyond an entrepreneurial ecosystem is analogous 
to a viral and self-reinforcing process in that as more and more actors beyond an entrepreneurial ecosystem perceive a venture as legitimate, so other connected actors assume the venture is appropriate and begin to take it for granted (Shepherd \& Zacharakis, 2003). This is turn causes other organizations to imitate it (Davis, 1991; Westphal, Gulati, \& Shortell, 1997) thereby further reinforcing the original entity's legitimacy outside of its ecosystem.

To the extent that a number of the characteristics of an entrepreneurial ecosystem and environments external to it are consistent with those that describe a network, it is important to examine how networks can influence new venture legitimacy. It is likely that entrepreneurial ecosystems will vary in the structural and relational dimensions of their networks. For example, some ecosystems will have more interactions and closer ties than others. In fact, by design in many cases, the interactions, support, and relationship building that occur in entrepreneurial ecosystems provide the opportunity for the creation of denser and stronger ties among the members of the ecosystem that can help entrepreneurs. Networks beyond those found in an ecosystem can have a variety of structural and relational dimensions. Baum et al. (2003) found small world network structures existing in the Canadian investment bank industry. These structures are characterized by cliques of highly-connected organizations that have a small number of intermediary organizations that connect the cliques. The cliques may have a large number of strong ties that promote internal information sharing, but the separation of cliques within a larger network can be illustrative of a more open network that is sparse with weak ties. Thus, an entrepreneur who is seeking legitimacy for his or her new venture within their ecosystem likely faces a somewhat different environment than when he or she tries to get the new venture legitimacy to spread beyond the ecosystem. Within an ecosystem, an entrepreneur 
may partner with high status actors in the ecosystem and such ties can serve as venture legitimation signals to other actors in the ecosystem (Elfring \& Hulsink, 2003). A visible tie with a high status actor within an entrepreneurial ecosystem suggests that the venture has been vetted the high status actor (Rindova, Petkova \& Kotha, 2007) and others within the ecosystem will lend credence to such judgements. Outside the ecosystem, an entrepreneur may find a large variety of networks that may be indifferent or even hostile to the new venture. Actors from outside an entrepreneurial ecosystem are much less likely to be aware of the status or reputation of venture partners from within the ecosystem, hence ties to such partners no longer serve as strong legitimating mechanisms when a venture moves beyond the ecosystem. For example, if the entrepreneur seeks legitimacy with organizations that are members of a dense network beyond the original ecosystem in which the venture was founded, the network members are more likely to be reliant on their strong network ties (Suarez, 2005) and closed-minded to different approaches unless those approaches' perceived value surpasses the network members' desire for internal conformity and to work within their trusted network. Even in more open networks outside the ecosystem, there are likely to be network members who must be convinced of the pragmatic benefits of working with a new venture before they are willing to consider changing their current approaches.

Jensen (2008) uses the terms exclusion and inclusion to refer to the extent that organizations in other networks are willing to collaborate with a new venture. Exclusion means that an organization prefers to not work with a new venture and inclusion means that an organization prefers to work with a new venture. Often times, these decisions are made for pragmatic, selfserving reasons as well as a reaction to the social embeddedness of the organization within their 
own network. Moving outside of an ecosystem is similar to moving beyond a network whereby the natural uncertainty of a new venture's products and services is compounded by the lack of familiarity these organizations have with the new venture (e.g. information asymmetry (Williamson, 1975, output quality (Podolny, 2001)). Thus, outside the entrepreneurial ecosystem, new venture legitimacy evaluations initially occur without the benefit of the connections found within the ecosystem. This can make it more difficult for the entrepreneur to gain positive legitimacy judgments outside the ecosystem, however a relatively more active and strategic approach may enhance potential success. Legitimacy diffusion may be more successful in a closed network with strong ties because the closeness of the network members enables enhanced trust and information sharing, from brokering for instance, than that which would be found among more sparsely connected organizations with weaker ties. In an approach similar to van Wijk et al. (2013), who describe how an innovation can lead to field change, knowledge about a new venture that is transmitted between network members with strong ties is more likely to be believed and result in less uncertainty thereby giving new venture legitimacy a stronger base for ongoing diffusion.

Proposition 7: New venture legitimacy brokering activities with others outside of an existing entrepreneurial ecosystem will result in greater legitimacy diffusion in dense networks with strong ties than in sparse networks with weak ties.

Bringing all this together highlights the paradox in the diffusion of new venture legitimacy. Individual legitimacy assessments about new ventures in the judgment phase are likely to be rapid and passive when a firm leverages existing technology to enter an existing market category and the entrepreneur uses a conformance strategy to legitimate the venture. However, such judgments are not likely to be relayed to others beyond an existing ecosystem. Therefore, the legitimacy of such ventures fails to spread across a population in the broad diffusion phase. 
Conversely, individual legitimacy assessments about a venture developing a new technology to create a new market category are likely to be slow and critical in the judgment phase as individual actors struggle to make sense of what the venture is doing and how it fits in because of all the newness embedded in the venture. Yet, after favorable legitimacy judgments, the diffusion of legitimacy about such ventures beyond the initial entrepreneurial ecosystem is likely to be rapid as actors within that ecosystem perceive it to be beneficial to share information about the novel and distinguishing features of the venture with others outside of the ecosystem. These paradoxical differences in the judgment and diffusion of new venture legitimacy are reflected in Table 1.

\section{Discussion}

An entrepreneurial ecosystem is orientated toward creating an environment conducive to the success of new entrepreneurial ventures. However, new ventures confront the challenge of establishing their credibility or legitimacy within and beyond that ecosystem. The concept of "newness" serves as both a source of competitiveness and as a liability for new ventures. Newness serves as a source of advantage in that new ventures often introduce new technologies and create new market categories to unlock new sources of value (Christensen, 1997;

Schumpeter, 1934). But newness is also a liability because the lack of performance history and consequent illegitimacy of new ventures serves as a burden when acquiring resources and when entering into ecosystem relationships (Aldrich \& Fiol, 1994; Stinchcombe, 1965). To overcome the illegitimacy burden, entrepreneurs engage in various approaches to legitimate a new venture including partnering with better-known organizations (Rindova, et al., 2007) and employing strategies such as: conformance, selection, manipulation and creation (Zimmerman \& Zeitz, 
2002). While these legitimation strategies are useful for understanding how entrepreneurs may overcome their illegitimacy challenges, existing literature provides little guidance on when each of these strategies is used in a productive way. Each of the various legitimation strategies is associated with different levels of cost and risk and hence it is important to understand when each is likely to be productively employed. Overall our theorizing indicates that as the level of technological and market newness within a new venture increases, so the strategies to foster legitimacy within an entrepreneurial ecosystem should become more strategic.

For a new venture to grow and to be able to access resources from a broader population beyond an entrepreneurial ecosystem the perceptions of new venture legitimacy need to diffuse. Although scholars have begun to consider how the legitimacy of a social object diffuses to a broad population (e.g. Johnson, et al., 2006; Tost, 2011), the nuances of legitimacy diffusion for new ventures operating in an entrepreneurial ecosystem have not yet been addressed. It is unclear how the strategies used to foster legitimacy for a new venture (e.g. conformance, selection, manipulation and creation [Zimmerman \& Zeitz, 2002]) impact the diffusion of legitimacy beyond an entrepreneurial ecosystem. Therefore, although the diffusion of legitimacy is critical for a new venture to be fully legitimated, the antecedents of diffusion are not well understood. To examine this issue we consider how individual judgments of new venture legitimacy are made and we assess the impact that such modes of judgment will have on whether information about the new venture is brokered across social networks extending beyond an existing entrepreneurial ecosystem. Overall our theorizing indicates that as the strategies to foster legitimacy become more strategic, individuals will engage in more active judgment of new venture legitimacy and, in turn, are more likely to share their legitimacy judgments with others 
beyond an entrepreneurial ecosystem, leading to higher levels of legitimacy diffusion.

This research integrates ideas from and adds to three different literatures. First, we describe a model reflecting the relative newness of entrepreneurial ventures thereby building on and adding to the literature at the intersection of entrepreneurship and innovation (e.g. Benner \& Tushman, 2003). Second, we utilize and extend concepts from the new venture legitimacy literature (e.g. Zimmerman \& Zeitz, 2002) to relate new venture newness to different legitimation strategies thereby explaining when and why different new venture legitimation strategies are productively employed within an entrepreneurial ecosystem. Third, we integrate ideas from the legitimacy diffusion literature (e.g. Johnson et al., 2006; Tost, 2011) to extend the applications of this literature to the new venture domain, and in so doing describe how different types of new venture newness and different legitimation strategies, result in different levels of legitimacy diffusion beyond an entrepreneurial ecosystem.

The conceptual insights emerging from the integration of these literatures highlight an important challenge for new ventures: entrepreneurs that pursue opportunities exploiting technological and market newness confront the greatest challenge in legitimizing their venture within an entrepreneurial ecosystem; but if they can clear a legitimacy threshold, information about their venture will spread more broadly and rapidly beyond the ecosystem in which it was established, resulting in high levels of legitimacy diffusion. Conversely entrepreneurs that create new organizations utilizing existing technology for an existing market category have an easier time legitimizing their venture with individuals within their ecosystem but the diffusion of new venture legitimacy beyond the borders of the ecosystem is likely to be limited. 
The process model and framework created in this manuscript point to a number of significant theoretical implications. First, new ventures that leverage new technologies and establish new market categories confront more significant legitimacy challenges than new ventures leveraging existing technology, entering an established market category or both. Leveraging new technology and establishing a new market category requires more effort, cost and risk on the part of an entrepreneur to meet the legitimacy threshold for new ventures. From a theoretical standpoint, it is useful to isolate dimensions that affect new venture newness so as to more readily recognize the legitimacy challenges confronted by such ventures.

Second, strategies employed to garner legitimacy for new ventures have an impact on how passive or active the judgment of new venture legitimacy is, which in turn impacts the likelihood that information about the venture will be brokered beyond an entrepreneurial ecosystem. Establishing an explicit connection between efforts to legitimate new ventures by those controlling the venture, and legitimacy judgments of new ventures by those evaluating the venture is an important advancement for research on new venture legitimacy. Tost (2011) integrated institutional theory and social psychology to outline a useful framework for considering factors impacting legitimacy judgments. We extend the ideas put forward by Tost (2011) by considering how they integrate with existing literature on new venture legitimacy. In so doing we are able to relate how the strategies employed by entrepreneurs to legitimate new ventures translate into legitimacy judgments by key audience members (within an entrepreneurial ecosystem). Although the link between legitimation activities and legitimacy judgments has been assumed in the literature on new venture legitimacy (e.g. Aldrich \& Fiol, 1994; Navis \& Glynn, 2011; Zimmerman \& Zeitz, 2002), the nature of this link has not yet been 
articulated. We theorize a specific set of relationships between legitimation strategies and legitimacy judgments to provide a useful theoretical connection between ventures and evaluators. Third, if new ventures are to access resources and enter into exchange relationships with those beyond the entrepreneurial ecosystem then they need to be perceived as legitimate by a broader population beyond the ecosystem. For this to happen, new venture legitimacy needs to diffuse. In our theorizing we describe how information brokering between actors in a social network is associated with the diffusion of new venture legitimacy beyond an existing ecosystem. Furthermore, we outline why information about some new ventures is more likely to be shared than others, thereby theorizing about which new ventures will experience higher and lower rates of legitimacy diffusion. Although the process of legitimacy diffusion has been the focus of recent theoretical advancements (e.g. Johnson et al., 2006), new venture legitimacy diffusion has not yet been considered, especially within the context of entrepreneurial ecosystems. Explicitly linking new venture legitimacy diffusion with legitimacy judgments and new venture legitimation strategies is a significant advancement in the literature on new venture legitimacy as well as the emerging literature on entrepreneurial ecosystems.

From a practical standpoint, there are a number of considerations that arise for entrepreneurs launching new ventures. First, by recognizing and understanding that technology and market newness impact legitimation efforts, revolutionary entrepreneurs - those creating ventures with radical new technologies and/or establishing new market categories — can more readily prepare to confront legitimation challenges as they embark on the process of establishing a new venture within an entrepreneurial ecosystem. They need to ensure that they have the resources and capacity to engage the legitimation effort required to meet the more challenging legitimation 
challenge immediately confronting their organization, and the recognition that once the initial legitimacy hurdle is passed the venture may have an easier time keeping the legitimation process going. In addition, as the legitimation process unfolds the ecosystem incumbents may also begin to engage in mutual adaptation with the new venture (Van Wijk, 2013), and this can create conditions whereby the acceptance of the new venture becomes even more pronounced. This is likely to be positively influenced by repeated interactions between the new venture and ecosystem members (Cattani et al., 2008). On the other hand, entrepreneurs with ventures that rely more on existing technologies and markets should understand that the increased likelihood of early legitimacy means they can save some of their resources for later periods when the legitimation process slows down.

Second, the theory outlined here suggests that entrepreneurs should aim to select and enact an appropriate legitimation strategy relative to the technology and market newness embedded in their venture. By fully assessing technology and market newness embedded in a venture and recognizing the linkage between such newness and legitimation strategies, entrepreneurs can ensure that there is appropriate alignment between the nature of the venture and the primary type of legitimation strategy adopted. If the legitimation strategy is out of alignment with the nature of the venture, then entrepreneurs may end up not investing enough in legitimation efforts, thereby never allowing their venture to clear the appropriate legitimacy threshold within an entrepreneurial ecosystem. Alternatively, if entrepreneurs invest too heavily in legitimation efforts they may squander valuable resources that are needed for other things in the development of a new venture. 
Third, because diverse actors make legitimacy assessments in an entrepreneurial ecosystem, they may invoke different institutional logics to determine legitimacy criteria and they may have different perceptions of what "newness" means with respect to technologies or markets. Actors familiar with certain technologies or certain markets may categorize certain ventures as far less "new" than those actors outside of those spheres. Thus, entrepreneurs may benefit from developing an understanding of the differing institutional logics and newness perceptions that characterize the new venture audience groups within and beyond an entrepreneurial ecosystem. Once identified, entrepreneurs can potentially utilize emphasis framing to quickly and strategically adjust salient elements of their presentations, pitches, videos, documents, or meeting discussions to emphasize specific legitimacy mechanisms that align with the institutional logic of the focal audience.

Fourth, the theory outlined here suggests that entrepreneurs should seek to understand who serves as a broker for their venture within an entrepreneurial ecosystem and they should aim (as much as possible) to nurture and encourage brokers so that information about the venture can spread, thereby fostering legitimacy diffusion beyond an existing ecosystem. Marketing research highlights the value of word-of-mouth marketing (Liu, 2006) and refers to the role of "evangelists" in nurturing a customer base for an organization (Moore, 1991). While these are somewhat related concepts, the role of an information broker in the diffusion of legitimacy for new ventures is still somewhat opaque. This research highlights how brokers play an important role in the general legitimation of new ventures and therefore entrepreneurs need to embrace and encourage brokers as much as possible. Furthermore, entrepreneurs need to provide brokers with something to talk about and give them an enticing reason to share information about their 
venture with other actors beyond their ecosystem (Berger, 2013; Elfring \& Hulsink, 2003).

\section{Future Research}

The conceptual linkages outlined here open up a number of opportunities for future research. One such opportunity is to use the framework as a basis for empirical testing. Linkages within the model could be tested in a number of different ways. Researchers might investigate how technology and market newness are related to the adoption of different legitimation strategies in new ventures. This could be done by analyzing the technology and market newness as reflected in venture business plans or pitch presentations and then coding those business plans and pitch presentations for different legitimation strategies. We would expect that new ventures with high levels of technological and market newness would reflect more strategic efforts at legitimation.

It may be possible to assess the speed of individuals in making legitimacy judgments about new ventures using an experimental design. One could create vignettes describing new ventures with different levels of technology and market newness and employing different legitimation strategies within an entrepreneurial ecosystem. It would then be possible to ask experiment participants to read the vignettes describing a venture and its legitimation efforts as a basis for

making legitimacy judgments about the venture (a similar approach was used by Zacharakis and Meyer, 1998) to understand venture capitalist investment decisions). In line with the theory described in this paper, one would predict that where a venture employs a high level of technological and market newness and therefore engages in more strategic legitimation strategies, that it would take participants longer to make legitimacy judgments. Such an experiment would also provide opportunities to extend our understanding of the link between 
venture newness, strategic legitimation efforts and individual legitimacy judgments because researchers could examine what happens when a venture with a high level of newness engages in a less strategic legitimation approach, or vice versa. This likely has an impact on the speed of individual legitimacy judgments and on the outcome of such decisions.

Researchers could also empirically examine the links between innovation newness and legitimacy diffusion for new ventures by examining how information about projects listed on crowd funding platforms (e.g. Kickstarter, Indiegogo) is shared between users. Crowdfunding platforms are becoming increasingly important for entrepreneurial ecosystems so they could provide opportunities for funders to share the details of a project with their ecosystems. The dynamics of our framework would predict that the higher the level of innovation newness the more likely that information about the project will be shared with others beyond the ecosystem. Therefore, researchers could assess the level of innovation newness in crowdfunding projects and use that as a basis to predict the likelihood that a funder will share information about the project beyond their ecosystem.

As we point out in section 8, legitimacy assessments represent social judgments that reside in the eye of the beholder and thus such assessments are audience dependent. In that section we pointed out new research that has delved into how legitimacy judgments differ across various audience contexts and highlighted the value of emphasis framing to enable an entrepreneur to establish legitimacy with these differing actors. However, future empirical research could explore how legitimacy judgments differ across various audience contexts within and beyond entrepreneurial ecosystems. This could be tested experimentally using a conjoint approach. By asking members 
of different ecosystem audiences (e.g. bankers, directors of incubators or accelerators, university administrators, professional service providers, and government officials that support entrepreneurial activity) to evaluate ventures with different configurations of legitimation mechanisms emphasized in different venture descriptions, researchers could identify and isolate the factors that influence different audience members.

An additional opportunity to extend this line of research is to further examine the role of brokers in legitimacy diffusion. In our model we conceptualized that information brokers play a critical role in sharing information about a new venture such that the legitimacy of the venture diffuses to a broader population within the entrepreneurial ecosystem. We conceptualized that all brokers behave in a similar way, sharing information that they have had to actively evaluate such that the legitimacy of a venture diffuses. However, it is conceivable that different types of information brokers exist such that different kinds of information are shared more or less under different conditions of the entrepreneurial ecosystem. In particular, the strength of ties between brokers and other members of networks may play a critical role in the extent to which information sharing is successful (Elfring \& Hulsink, 2003), since stronger ties may be more useful than weaker ties when newer or radical ideas are present. The categorization of different types of information brokers can therefore be elaborated on in future research so as to better understand what types of brokers generate higher or lower levels of legitimacy diffusion beyond an entrepreneurial ecosystem.

\section{Conclusion}


The model linking innovation newness, legitimation strategies and legitimacy diffusion presented here incorporates ideas from the entrepreneurship and innovation literature and from various elements of the legitimacy literature. The integration of ideas from these different literatures lays a foundation for a more nuanced understanding of newness and legitimacy in the entrepreneurial ecosystem. The model allows us to consider how legitimation operates across different levels of analysis when developing new ventures_-including the organizational level, the individual level and the population level. In so doing the model provides a basis for understanding how the "newness" of a new venture relates to the strategies employed to legitimize it, and how the legitimation strategies employed relate to the judgment and diffusion of new venture legitimacy within an entrepreneurial ecosystem. By presenting this framework, we hope to stimulate further inquiries into the linkages between newness, legitimation, judgment and diffusion within entrepreneurial ecosystems. 


\section{References}

Abernathy, W. J., \& Clark, K. B. (1985). Innovation: Mapping the winds of creative destruction. Research Policy, 14(1), 3-22.

Acs, Z. J., Autio, E., \& Szerb, L. (2014). National systems of entrepreneurship: Measurement issues and policy implications. Research Policy, 43(3), 476-494.

Aldrich, H. E., \& Fiol, C. M. (1994). Fools rush in? The institutional context of industry creation. The Academy of Management Review, 19(4), 645-670.

Alexy, O. \& George, G. (2013). Category divergence, straddling, and currency: Open innovation and the legitimation of illegitimate categories. Journal of Management Studies, 50(2), 173203.

Anderson, C. R., \& Zeithaml, C. P. (1984). Stage of the product life cycle, business strategy, and business performance. Academy of Management Journal, 27(1), 5-24.

Ashforth, B. E., \& Gibbs, B. W. (1990). The double-edge of organizational legitimation. Organization Science, 1, 177-194.

Audretsch, D.B., Kuratko, D.F., \& Link, A.N. (2015). Making sense of the elusive paradigm of entrepreneurship, Small Business Economics, 45 (4), 703-712.

Bae, J., Wezel, F. C., \& Koo, J. (2011). Cross-cutting ties, organizational density, and new firm formation in the U.S. biotech industry, 1994-1998. Academy of Management Journal, 54(2), 295-311.

Baker, T., \& Nelson, R.E. (2005). Creating something from nothing: Resource construction through entrepreneurial bricolage. Administrative Science Quarterly 50 (3), 329-66.

Baum, J. A. C., Shipilov, A. V., Rowley, T. J. (2003). Where do small worlds come from?

Industrial and Corporate Change 12(4), 697-725.

Berger, J. (2013). Contagious: Why things catch on. Simon and Schuster.

Benner, M. J., \& Tushman, M. L. (2003). Exploitation, exploration, and process management: The productivity dilemma revisited. Academy of Management Review, 28(2), 238-256.

Bitektine, A. (2011). Toward a theory of social judgments of organizations: The case of legitimacy, reputation, and status. Academy of Management Review, 36, 151-179.

Brint, S., \& Karabel, J. (1991). Institutional origins and transformation: The case of American community colleges. In W. W. Powell \& P. J. DiMaggio (Eds.), The new institutionalism in organizational analysis: 337-360. Chicago: University of Chicago Press.

Burt, R. S. (1987). Social contagion and innovation: Cohesion versus structural equivalence. American Journal of Sociology, 92 (6), 1287-1335.

Burt, R. S. (2005). Brokerage and closure: An introduction to social capital. Oxford University Press.

Carbonell-Foulquié, P., Munuera-Alemán, J. L., \& Rodrıguez-Escudero, A. I. (2004). Criteria employed for go/no-go decisions when developing successful highly innovative products. Industrial Marketing Management, 33(4), 307-316.

Cattani, G., Ferriani, S., Negro, G., \& Perretti, F. (2008). The structure of consensus: Network ties, legitimation, and exit rates of U.S. feature film producer organizations. Administrative Science Quarterly, 53 (1), 145-182.

Christensen, C.M. (1997). The innovator's dilemma. Boston: Harvard Business Review Press.

Cohen, B. (2006). Sustainable valley entrepreneurial ecosystems. Business Strategy and the Environment, 15(1), 1-14.

Covin, J. G., Slevin, D. P., \& Heeley, M. B. (2000). Pioneers and followers: Competitive tactics, environment, and firm growth. Journal of Business Venturing, 15, 175-210. 
Crossan, M. M., \& Apaydin, M. (2010). A multi-dimensional framework of organizational innovation: A systematic review of the literature. Journal of Management Studies, 47, 1154-1191.

Day, G. S. (2007). Is it real? Can we win? Is it worth doing? Managing risk and reward in an innovation portfolio. Harvard Business Review, 85(12), 110.

Davies, M., \& Prince, M. (2005). Dynamics of trust between clients and their advertising agencies: Advances in performance theory. Academy of Marketing Science Review, 11(1), 132.

Davis, G. F. (1991). Agents without principles? The spread of the poison pill through the intercorporate network. Administrative Science Quarterly, 36 (4), 583-613.

Delmar, F., \& Shane, S. (2004). Legitimating first: Organizing activities and the survival of new ventures. Journal of Business Ventures, 19, 385-410.

DiMaggio, P., \& Powell, W. (1983). The iron cage revisited: Institutional isomorphism and collective rationality in organizational fields. American Sociological Review, 48, 147-160.

Drucker, P.F. (1985). Innovation and entrepreneurship (New York: Harper \& Row).

Eckhardt, J.T. \& Shane, S.A. (2011). Industry changes in technology and complimentary assets and the creation of high-growth firms, Journal of Business Venturing, 26 (4), 412-430.

Elfring, T. \& Hulsink, W. (2003). Networks in entrepreneurship: The Case of high-technology firms. Small Business Economics, 21 (4), 409-422.

Fligstein, N. (1991). The structural transformation of American industry: An institutional Account of the causes of diversification in the largest firms. In W. W. Powell \& P. J. DiMaggio (Eds.), The New Institutionalism in Organizational Analysis: 311-336. Chicago: University of Chicago Press.

Fisher, G., Kotha, S. \& Lahiri, A. (2016). Changing with the times: An integrated view of identity, legitimacy and new venture life cycles. Academy of Management Review, 41(3), 127.

Fisher, G., Kuratko, D.F., Bloodgood, J., \& Hornsby, J.S. (2017). Legitimate to whom? The challenge of audience diversity and new venture legitimacy. Journal of Business Venturing, 32 (1), In Press.

Fiske, S. T., \& Taylor, S. E. (1984). Social cognition (1st ed.). Reading, MA: Addison-Wesley.

Garcia, R., \& Calantone, R. (2002). A critical look at technological innovation typology and innovativeness terminology: a literature review. Journal of Product Innovation Management, 19(2), 110-132.

Garrett, R. P., Covin, J. G., \& Slevin, D. P. (2009). Market responsiveness, top management risk taking, and the role of strategic learning as determinants of market pioneering. Journal of Business Research, 62, 782-788.

Gilbert, B.A., McDougall, P.P., \& Audretsch, D.B. (2006). New venture growth: A review and extension. Journal of Management, 32(6), 926-950.

Gundry, L.K., Kickul, J.R., Griffiths, M.D., \& Bacq, S.C. (2011). Creating social change out of nothing: The role of entrepreneurial bricolage in social entrepreneurs' catalytic innovations. Advances in Entrepreneurship, Firm Emergence and Growth, 13 (7), 1-24.

Hart, M., Roberts, M. J., \& Stevens, J. D. (2005). Zipcar: Refining the business model. Harvard Business School Press.

Henderson, R. M., \& Clark, K. B. (1990). Architectural innovation: the reconfiguration of existing product technologies and the failure of established firms. Administrative Science Quarterly, 35 (1), 9-30. 
Isenberg, D. J. (2010). How to start an entrepreneurial revolution? Harvard Business Review, 88(6), 40-50.

Isenberg, D. (2011). Introducing the entrepreneurial ecosystem: Four defining characteristics. Forbes, May 25, 2011. http://www.forbes.com/sites/danisenberg/2011/05/25/introducing-theentrepreneurship-ecosystem-four-defining-characteristics/

Jensen, M. (2008). The use of relational discrimination to manage market entry: When do social status and structural holes work against you? Academy of Management Journal, 51(4), 723743.

Johnson, C., Dowd, T. J., \& Ridgeway, C. L. (2006). Legitimacy as a social process. Annual Review of Sociology, 32, 53-78.

Kahneman, D. (2011). Thinking, fast and slow. New York: Macmillan.

Kuratko, D.F. (2017). Entrepreneurship: Theory, process, practice, $10^{\text {th }}$ ed. (Mason, OH: Cengage/Southwestern).

Kuratko, D. F., Morris, M. H., \& Schindehutte, M. (2015). Understanding the dynamics of entrepreneurship through framework approaches. Small Business Economics, 45(1), 1-13.

Lawrence, T. B., \& Suddaby, R. (2006). 1.6 Institutions and institutional work. The Sage handbook of organization studies, 215.

Liu, Y. (2006). Word of mouth for movies: Its dynamics and impact on box office revenue. Journal of Marketing, 70 (3), 74-89.

Lumpkin, G. T., \& Dess, G. G. (1996). Clarifying the entrepreneurial orientation construct and linking it to performance. Academy of Management Review, 21(1), 135-172.

Malecki, E. J. (2011). Connecting local entrepreneurial ecosystems to global innovation networks: open innovation, double networks and knowledge integration. International Journal of Entrepreneurship and Innovation Management, 14(1), 36-59.

Martens, M. L., Jennings, J.E., \& Jennings, P. E. (2007). Do the stories they tell get them the money they need? The role of entrepreneurial narratives in resource acquisition. Academy of Management Review, 50, 1107-1132.

McKelvie, A. \& Wiklund, J. (2010). Advancing firm growth research: A focus on growth mode instead of growth rate. Entrepreneurship Theory and Practice, 34 (2), 261-288.

Meyer, J. W., \& Rowan, B. (1977). Institutionalized organizations: Formal structure as myth and ceremony. American Journal of Sociology: 83, 340-363.

Miller, A., \& Dess, G. G. (1996). Strategic management (2nd ed.). New York: McGraw-Hill.

Moore, G. A. (1991). Crossing the chasm. New York: Harper Business

Morris, M.H., Neumeyer, X., \& Kuratko, D.F. (2015). A portfolio perspective on entrepreneurship and economic development, Small Business Economics, 45 (4), 713-728.

Mueller, B.A., Titus, V.K., Jr., Covin, J.G., and Slevin, D.P. (2012). Market pioneering and firm growth: Knowing when and to what degree pioneering makes sense. Journal of Management, 38(5), 1517-1549.

Nambisan, S., \& Baron, R. A. (2013). Entrepreneurship in innovation ecosystems: Entrepreneurs' self-regulatory processes and their implications for new venture success. Entrepreneurship Theory and Practice, 37(5), 1071-1097.

Navis, C., \& Glynn, M. A. (2010). How new market categories emerge: Temporal dynamics of legitimacy, identity and entrepreneurship in satellite radio, 1990-2005. Administrative Science Quarterly, 55(3), 439-471. 
Navis, C., \& Glynn, M. A. (2011). Legitimate distinctiveness and the entrepreneurial identity: Influence on investor judgments of new venture plausibility. Academy of Management Review, 36(3), 479-499.

Oliver, C. (1990). Determinants of interorganizational relation- ships: Integration and future directions. Academy of Management Review, 15, 241-265.

Pahnke, E. C., Katila, R., \& Eisenhardt, K. M. (2015). Who takes you to the dance? How partners' institutional logics influence innovation in young firms. Administrative Science Quarterly, 60, 596-633.

Podolny, J.M. (2001). Networks as the pipes and prisms of the market. American Journal of Sociology, 107 (1), 33-60.

Pollock, T. G., \& Rindova, V. P. (2003). Media legitimation effects in the market for initial public offerings. Academy of Management Journal, 46(5), 631-642.

Powell, W. W. (1991). Expanding the scope of institutional analysis. In W. W. Powell \& P. J. DiMaggio (Eds.), The new institutionalism in organizational analysis: 183-203. Chicago: University of Chicago Press.

Rampersad, G., Quester, P., \& Troshani, I. (2010). Examining network factors: commitment, trust, coordination and harmony. Journal of Business \& Industrial Marketing, (25) 7, 487 500.

Rampersad, G., Quester, P., \& Troshani, I. (2010). Managing innovation networks: Exploratory evidence from ICT, biotechnology and nanotechnology networks. Industrial Marketing Management, 39(5), 793-805.

Rindova, V.P., Petkova, A.P., \& Kotha, S. (2007). Standing out: how new firms in emerging markets build reputation. Strategic Organization, 5 (1), 31-70.

Rogers, E. M. (2010). Diffusion of innovations. New York: Simon and Schuster.

Saxenian, A. (1996). Regional advantage: Culture and competition in Silicon Valley and Route 128. Harvard University Press.

Schumpeter J. (1934). The theory of economic development. Harvard University Press: Cambridge, MA.

Scott, W. R. (1995). Institutions and organizations. Thousand Oaks, CA: Sage.

Shane, S. (2009). Why encouraging more people to become entrepreneurs is bad public policy. Small Business Economics, 33(2), 141-149.

Shepherd, D. A., \& Zacharakis, A. (2003). A new venture's cognitive legitimacy: An assessment by customers. Journal of Small Business Management, 41(2), 148-167.

Sine, W. D., David, R. J., \& Mitsuhashi, H. (2007). From plan to plant: Effects of certification on operational start-up in the emergent independent power sector. Organization Science, 18, $578-594$

Singh, J. V., Tucker, D. J., \& House, R. J. (1986). Organizational legitimacy and the liability of newness. Administrative Science Quarterly, 31(2), 171-193.

Sorenson, O. \& Stuart, T. E. (2001). Syndication networks and the spatial distribution of venture capital investments. American Journal of Sociology, 106(6), 1546-1588.

Stam, E. (2015). Entrepreneurial ecosystems and regional policy: A sympathetic critique. European Planning Studies, 23(9), 1759-1769.

Starr, J. A., \& MacMillan, I. C. (1990). Resource cooptation and social contracting: Resource acquisition strategies for new ventures. Strategic Management Journal, 11, 79-92.

Stinchcombe, A. L. (1965). Social structure and organizations. In J. G. March (Ed.), Handbook of Organizations (pp. 153-193). Chicago: Rand McNally. 
Stringfellow, L., Shaw, E., \& Maclean, M. (2014). Apostasy versus legitimacy: Relational dynamics and routes to resource acquisition in entrepreneurial ventures. International Small Business Journal, 32 (5), 571-592.

Stuart, T. E. \& Sorenson, O. (2007). Strategic networks and entrepreneurial ventures. Strategic Entrepreneurship Journal, 1, 211-227.

Suarez, F. F. (2005). Network effects revisited: The role of strong ties in technology selection. Academy of Management Journal, 48(4), 710-720.

Suchman, M. A. (1995). Managing legitimacy: Strategic and institutional approaches. Academy of Management Review, 20(3), 571-610.

Tornikoski, E. T. \& Newbert, S. L. (2007). Exploring the determinants of organizational emergence: A legitimacy perspective. Journal of Business Venturing, 22, 311-335.

Tost, L. P. (2011). An integrative model of legitimacy judgments. Academy of Management Review, 36(4), 686-710.

Tushman, M. L., \& Anderson, P. (1986). Technological discontinuities and organizational environments. Administrative Science Quarterly, 31 (3), 439-465.

Van Wijk, J., Stam, W., Elfing, T., Zietsma, C., \& Den Hond, F. (2013). Activists and incumbents structuring change: The interplay of agency, culture, and networks in field evolution. Academy of Management Journal, 56 (2), 358-386.

Wind, J., \& Mahajan, V. (1997). Editorial: issues and opportunities in new product development: an introduction to the special issue. Journal of Marketing Research, 34(1), 1-12.

Westphal, J. D., Gulati, R., \& Shortell, S. M. (1997). Customization or conformity? An institutional and network perspective on the content and consequences of TQM adoption. Administrative Science Quarterly, 42 (2), 366-394.

Williamson, O. E. 1975. Markets and hierarchies: Analysis and antitrust implications. The Free Press: New York.

Zacharakis, A. L., \& Meyer, G. D. (1998). A lack of insight: Do venture capitalists really understand their own decision processes? Journal of Business Venturing, 13(1), 57-76.

Zhou, K. Z., Kin, C., \& Tse, D. K. (2005). The effects of strategic orientations on technologyand market-based breakthrough innovations. Journal of Marketing, 69 (2), 42-60.

Zimmerman, M. A., \& Zeitz, G. J. (2002). Beyond survival: Achieving new venture growth by building legitimacy. The Academy of Management Review, 27(3), 414-431.

Zott, C., \& Huy, Q. N. (2007). How entrepreneurs use symbolic management to acquire resources. Administrative Science Quarterly, 52, 70-105.

Zuckerman, E. W. (1999). The categorical imperative: Securities analysts and the illegitimacy discount. American Journal of Sociology, 104(5), 1398-143 
Figure 1. Entrepreneurial newness

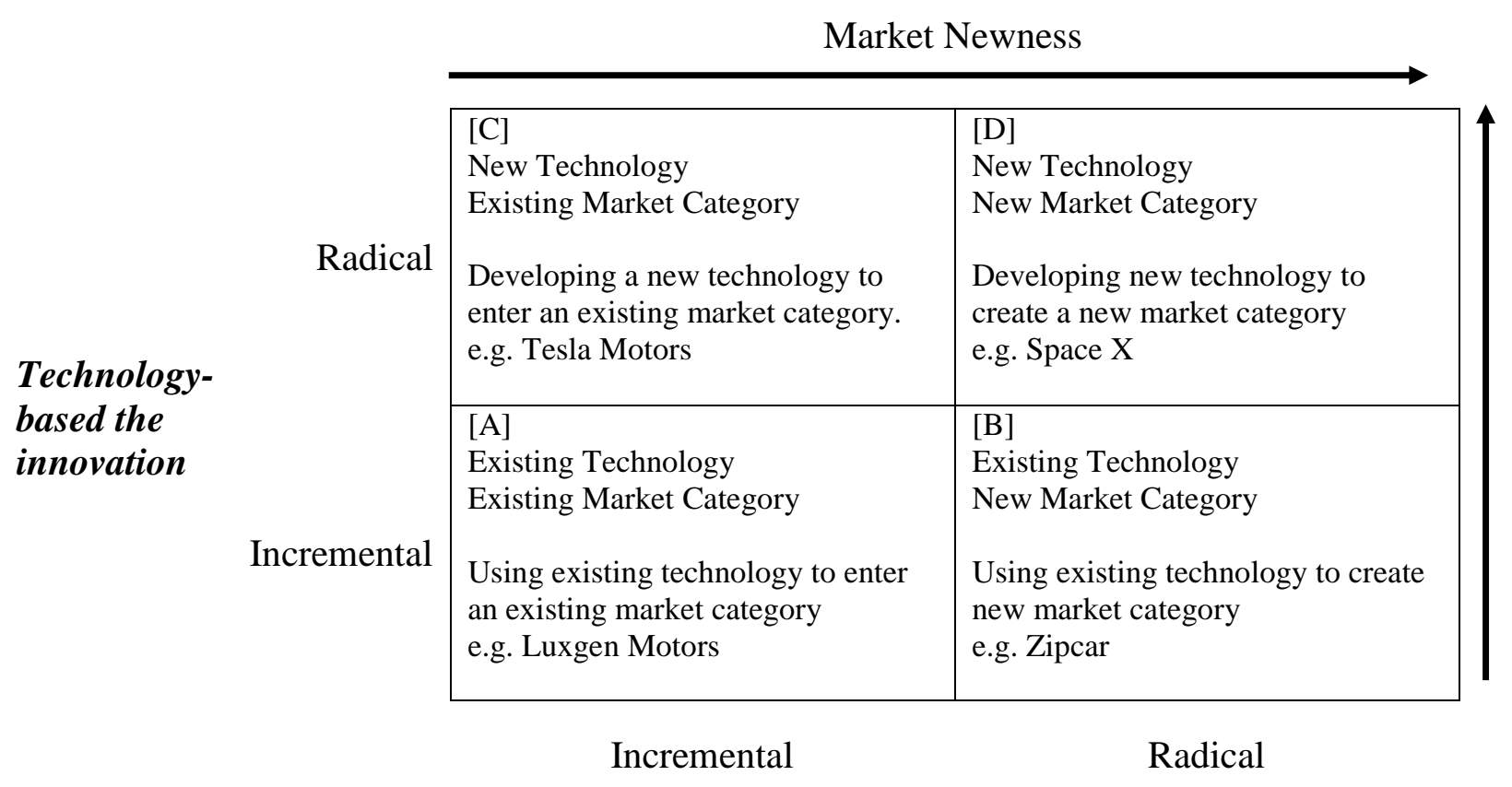

Market-based innovation 
Table 1. Phases of New Venture Legitimation

\begin{tabular}{|c|c|c|c|}
\hline Innovation Phase & Strategy Phase & $\begin{array}{l}\text { Local Validation } \\
\text { Phase (within } \\
\text { existing ecosystem) }\end{array}$ & $\begin{array}{l}\text { Broad Diffusion } \\
\text { Phase (beyond } \\
\text { existing ecosystem) }\end{array}$ \\
\hline $\begin{array}{l}\text { Quadrant A } \\
\text { - Existing } \\
\text { Technology } \\
\text { Existing Market } \\
\text { Category }\end{array}$ & $\begin{array}{l}\text { Conformance strategy (P1) } \\
\text { Portray the venture as conforming } \\
\text { with existing rules and norms of the } \\
\text { industry (Zimmerman \& Zeitz, } \\
\text { 2002) }\end{array}$ & $\begin{array}{r}\text { Passive judgment } \\
\qquad(\text { (P5) }\end{array}$ & $\begin{array}{c}\text { Narrow diffusion } \\
\qquad{ }_{(\mathrm{P} 6)}\end{array}$ \\
\hline $\begin{array}{l}\text { Quadrant B } \\
\text { - Novel } \\
\text { Innovation } \\
\text { - Existing Market } \\
\text { Category }\end{array}$ & $\begin{array}{l}\text { Selection strategy (P2) } \\
\text { Locating in a favorable } \\
\text { environment (Scott, 1995; } \\
\text { Suchman, 1995) } \\
\text { Position in an environment where } \\
\text { "early adopters" are exposed to the } \\
\text { venture. }\end{array}$ & & \\
\hline $\begin{array}{l}\text { Quadrant C } \\
\text { - Existing } \\
\text { Technology } \\
\text { - New Market } \\
\text { Category }\end{array}$ & $\begin{array}{l}\text { Manipulation strategy (P3) } \\
\text { Preemptive intervention in the } \\
\text { cultural environment to develop } \\
\text { bases of support tailored to the } \\
\text { needs of the organization } \\
\text { (Suchman, 1995; Zimmerman \& } \\
\text { Zeitz, 2002) }\end{array}$ & & \\
\hline $\begin{array}{l}\text { Quadrant D } \\
\text { - Novel } \\
\text { Innovation } \\
\text { New Market } \\
\text { Category } \\
\end{array}$ & $\begin{array}{l}\text { Creation strategy (P4) } \\
\text { Creation of the social context - } \\
\text { rules, norms, values, beliefs, } \\
\text { models, etc. (Zimmerman \& Zeitz, } \\
\text { 2002) }\end{array}$ & Active evaluation & Wide diffusion \\
\hline
\end{tabular}


Figure 2. New Venture Legitimation Process

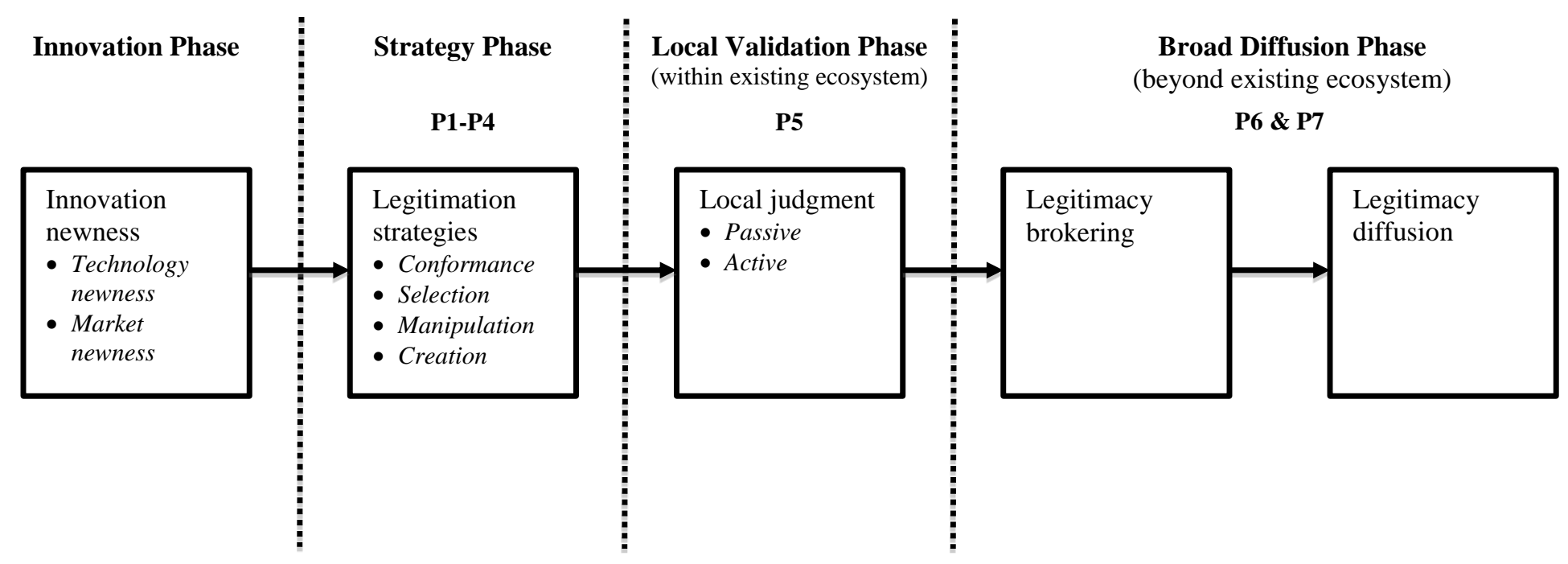

